\title{
Centralized Testing Communication Document
}

National Cancer Institute

\section{Source}

National Cancer Institute. Centralized Testing Communication Document. NCI

Thesaurus. Code C115639.

Records of communications related to a centralized test. 